\title{
THE STANDING OF THE PUBLIC INTEREST ${ }^{1}$
}

\begin{abstract}
Amitai Etzioni
Recebido em: 26/07/ 2016 Aceito em: 20/09/2016

etzioni@gwu.edu

Liberal communitarianism holds that a good society is based on a carefully crafted balance between individual rights and the common good; that both normative elements have the same fundamental standing and neither a priori trumps the other. Societies can lose the good balance either by becoming excessively committed to the common good (e.g. national security) or to individual rights (e.g. privacy). Even societies that have established a careful balance often need to recalibrate it following changes in historical conditions (such as the 2001 attacks on the American homeland) and technological developments (such as the invention of smart cell phones).

This article responds to those who reject the very conception of a common good (or the public interest) on a variety of philosophical and methodological grounds. It then asks how the American courts, in particular the Supreme Court, define the common good, what weight the courts have granted the common good versus individual rights, and what criteria they have employed in rendering these judgments in three key areas: that of free speech, public safety, and a major form of taking, that of eminent domain.

To cover these vast subjects, the article by necessity employs very broad strokes. Readers may allow the author to indulge in these if they keep in mind that the article seeks to make merely a few limited points, though to make these requires covering a great deal of ground. What is considered a common good and the relative normative standing it commanded varied over history. These historical changes require a separate treatment, from society to society in the same time frame. The discussion here focuses on the modern era, in the United States.
\end{abstract}

\section{WHAT IS A COMMON GOOD?}

The common good (alternatively called 'the public interest' or 'public goods') denotes those goods that serve all members of a given community and its institutions, and, as such, includes both goods that serve no identifiable particular group, as well as those that serve members of generations not yet born. It is a normative concept with a long and contested history. Philosophers, theologians, lawyers, politicians, and the public have arrived at distinct understandings about what the common good entails, how it should be balanced against individual goods, and if and by whom it should be enforced. Though there are many critics of the concept of the common good (discussed below), it has survived as a meaningful concept for well over two millennia, and continues to serve as a very significant organizing principle of civic and political life.

The common good has deep roots in the history of philosophical and religious thought. For Plato 'the good' was objective, defined as that which "every soul pursues $[\ldots]$ and does whatever it does for its sake."3 Arriving at knowledge of the good within a community would create unity, which is "the greatest blessing for a state." 4 In this conception there is no tension between the private and public good, as individuals are thought to attain happiness (a private good) through the pursuit of justice (a public good). For Aristotle, "a polis exists for the sake of a good life," and human beings, as political animals, lead a good life by contributing to the good of the community. ${ }^{5}$ He asks, What sort of people do we want society to form, and how should we structure society to accomplish this? This

\footnotetext{
${ }^{1}$ I am indebted to Rory Donnelly for research assistance and to Professor Scott Cummings for comments on a previous draft. Article former published at Barry Law Review Volume 20.2 (Spring 2015, pp. 191-217).

${ }^{2}$ Professor of International Relations and Director of the Institute for Communitarian Policy Studies at The George Washington University, USA.

3 Plato, Republic, Bk VI, 1126 (505e).

${ }^{4}$ Plato, Republic Bk. V. p. 464

${ }^{5}$ Aristotle Politics, 1280 a 31-32.
} 
question presupposes a society that has a shared end that both is separate from and actively shapes the good of the individual. The ancient Roman philosophers had a similarly robust conception of the common good. Cicero, writing around 50 B.C., defined a "people" or "republic" as "not any collection of human beings brought together in any sort of way, but an assemblage of people in large numbers associated in agreement with respect to justice and a partnership for the common good."

Often drawing on Greek and Roman tradition, Christian theologians have explored the common good. In City of God, Augustine takes up Cicero's definition of a republic as a people joined by their pursuit of the common good, and specifies the content of that good from a Christian perspective: the good is none other than God, and to pursue the common good is to render unto God the love and worship that is His due. Thomas Aquinas maintains a theological conception of the common good: "God's own goodness...is the good of the whole universe."7

The place of the common good in modern (neoclassical) economics has its origins in the Enlightenment conception of society as existing "in order to further the goals of individuals, neither asking where the goals of individuals come from, nor inquiring into the processes by which individuals are formed in society." ${ }^{\prime 8}$ In neoclassical economics, the common good is not an objective goal to be discerned and pursued, but rather the aggregation of individual goods. This idea was first articulated by Adam Smith, who posited that man, in pursuing his own personal gain, unwittingly "promotes that of the society more effectually than when he really intends to promote it."

In this view, the common good-the summation of all private goods-arises naturally from economic exchanges, and no state efforts are needed to promote it. Indeed, attempts to guide the preferences of individuals towards a common goal are seen, at best, as paternalism, and at worst, as the first step on the road to totalitarianism, as was famously argued by Friedrich A. Hayek in The Road to Serfdom. ${ }^{10}$

Economists, though, have introduced exceptions to this rule for situations in which the invisible hand is unable to provide "public goods" that benefit society at large. The market's inability to produce such goods reflect what economists call a "market failure" (an instance where the market is unable to achieve an efficient allocation of resources) and thus government intervention in the production of these goods is tolerated. Examples of public goods include defense, basic research, and public health (e.g. fluoridation and vaccinations). Thus, Kenneth J. Arrow wrote that "we expect a free enterprise economy to underinvest in invention and research (as compared with an ideal) because it is risky, because the product can be appropriated only to a limited extent, and because of increasing returns in use. This underinvestment will be greater for more basic research."11

\footnotetext{
${ }^{6}$ Cicero, On the Commonwealth (Sabine/Smith Translation, 1929) p. 129

${ }^{7}$ Aquinas, Summa Theologiae, la, llae, q. 19, art. 10.

${ }^{8}$ Andrew M. Yuengert, The Common Good for Economists, 38 Faith and Economics 3 (2001), accessed at https://www.gordon.edu/ace/pdf/Yuengert=F\&E38.pdf

${ }^{9}$ Adam Smith, The Wealth of Nations, edition U. of Chicago, p. 477 (1776)

${ }^{10}$ Friedrich von Hayek, The Road to Serfdom (1944)

${ }^{11}$ Kenneth Joseph Arrow, Economic Welfare and the Allocation of Resources for Invention in The Rate and Direction of Inventive Activity: Economic and Social Factors p. 619 (1962), accessed at http://www.nber.org/chapters/c2144.pdf
} 
The pluralist tradition of political science, which largely adopts the assumptions of neoclassical economics, has little room for a robust notion of the public interest, and in some cases criticizes such a notion as implicitly anti-democratic. Pluralist thinkers, drawing upon their theory's economic underpinnings, argue that in a free and robust democracy competition among interest groups-which reveal and are guided by the preferences of individuals (i.e., private goods)—gives rise to a public policy that maximizes general welfare. The representative function of such a political system is preserved both because all individuals are free to associate with any number of these groups, and because each group can only exercise pressure equivalent to its popular support. Political scientists in the pluralist tradition readily criticize top-down notions of the public interest and the common good as inviting authoritarianism at the expense of procedural democracy. Thus, Frank Sorauf argued that the tug of war between private interests groups produces public policy superior to anything that would be reached by the state enforcing its own formulation of the public interest. ${ }^{12}$

Critics argue that discrepancies in wealth, power, and social status give groups varying degrees of leverage over the government, and as a result public policy-based on interest group politics-does not maximize social welfare (i.e., that aggregation of individual goods), much less reflect a robustly defined common good, but rather serves the interests of the politically and economically powerful. Moreover, interest group pluralists fail to properly incorporate notions of the public good into their normative framework.

In less individualistic societies-many of them non-Western-the value of the common good is rarely questioned. However, the normative status of the common good-unlike that of rights-is far from self-evident to many in the West. The use of the term 'the common good' is contested on a number of fronts. First, there are those who argue that it does not exist at all. Ayn Rand wrote that 'Since there is no such entity as 'the public,' since the public is merely a number of individuals, the idea that 'the public interest' supersedes private interests and rights, can have but one meaning: that the interests and rights of some individuals take precedence over the interests and rights of others."13

Communitarians counter that the common good does not merely amount to an aggregation of all private or personal goods in a society. Contributions to the common good often offer no immediate payout or benefit. It is frequently impossible to predict who the beneficiaries will be in the long run. Still, members of communities that support the common good invest in it not because it will necessarily or even likely benefit them personally, or even their children, but simply because they consider it a good that ought to be nurtured. They consider it the right thing to do-by itself, for itself. This explanation surprises only those who claim that, even when we act in clearly altruistic ways, we always have an ulterior, self-serving motive. For everyone else, examples of such common goods are readily apparent: in addition to national defense and basic research, discussed above, public health and environmental preservation are widely accepted examples of common goods. The non-selfinterested nature of these measures stands out especially when serving the common good entails not merely some minor costs to the individual (e.g., taxes) but the existential risks of certain forms of service such as fighting for one's country.

\footnotetext{
${ }^{12}$ Frank Sorauf, Party and representation, legislative politics in Pennsylvania (1962)

${ }^{13}$ Ayn Rand, The Monument Builders in The Virtue of Selfishness 88 (1964)
} 
Protecting the environment, preventing climate change, and developing sustainable energy sources are all costly projects that will only pay off over the longer run, and then only to unknown, unpredictable beneficiaries. The millions of people who are working towards these goals today cannot be sure that they will be alive to see the full impact of their work. Self-interest-maximizing individuals would gain a much better rate of return on their money if they invested in readily-available financial instruments such as stocks and bonds, and then used the dividends to purchase air conditioners and sunscreen.

In response to this account of the common good, libertarians have developed elaborate arguments that explain why people invest in these common goods that do not necessarily benefit them, without giving up on their assumption that people are rational utility maximizers. For example, Anthony Downs, Gordon Tullock, and William Riker all wondered why a rational actor would vote. These social scientists assumed that "the voter calculates the expected utility from each candidate's victory, and naturally votes for the candidate whose policies promise the highest utility." probability that any one voter's ballot will affect the outcome of all but the closest elections is virtually zero. As voting always imposes at least some costs, costs that almost always outweigh the expected benefit, Downs et al. argued that people vote because they believe that the results will be close and hence their one vote could decide the election, a personal benefit that would offset the individual cost of their effort. However, it turns out that many millions vote even when elections are known not to be close.

Moreover, the evidence shows that the most important factor that explains whether a person will vote is the extent to which the person considers voting his or her duty as a citizen. André Blais writes that "about half the electorate ... vote out of a strong sense of moral obligation, because they believe it would be wrong not to vote; they do not calculate benefits and costs." ${ }^{15}$

A second criticism of the common good comes from those on the left who hold that the concept-as manifested, for instance, in the call to serve the 'fatherland' or 'mother church'-serves to conceal class differences in economic interests and political power so as to keep those who are disadvantaged from making demands on the community. These critics are correct in asserting that this concept can be abused in this way. However, the fact that a concept is abused-a common fate of compelling concept-does not mean that it is without great merit. Otherwise, we would have to do away with such concepts as science, rationality, and community, all of which have been misappropriated. That said, one best considers what particular goods the calls to serve "the" common good seek to serve.

Finally, several academic communitarians, in particular Michael Sandel and Charles Taylor, argue that any conception of the good must be formulated on the social level, and that the community cannot be a normative-neutral realm. Moreover, unless there is a social formulation of the good, there can be no normative foundation for resolving conflicts of value between different individuals and groups. Such an overriding good (e.g., the national well-being) enables persons with different moral outlooks or ideological backgrounds to find principled (rather than merely prudential) common ground.

\footnotetext{
${ }^{14}$ Dennis C. Mueller, Public Choice III 304 (2003)

${ }^{15}$ Andre Blais, To Vote or not to Vote?: The Merits and Limits of Rational Choice Theory 137 (2000)
} 
Communities are the most likely source of particular specifications of the common good. Some have argued that the term 'community' is so vague it cannot even be defined. In contrast, communitarians hold that community can be clearly defined as a group of individuals that possesses two characteristics. The first is a web of affect-laden relationships which often crisscross and reinforce one another (rather than merely one-on-one or chain-like individual relationships). The second characteristic shared by the individuals of a community is some commitment to a core of shared values, norms, and meanings, as well as a collective history and identity-in short, a particularistic moral culture. Responsive (or liberal) communitarians hold that community is basically a major common good in itself as well as a major source of other common goods; "basically" because like all goods, community can take on dysfunctional forms, especially when its social bonds, culture, or political structure are oppressive. Hence the special import of balancing the community as a value with commitments to individual rights.

To state that a given value is a common good of a given community does not mean that all the members subscribe to it, and surely not that they all live up to its dictates. It suffices that the value be recognizes as a common good by large majorities and be embodied in law and in other institutions. At the same time, a value to which members merely pay lip service cannot qualify. We shall see below that it is essential for solid analysis to consider the extent to which values are institutionalized as a continuous variable rather than as a dichotomous one. Some values are relatively highly institutionalized, e.g. marriages in the US in 1950s. Others are merely aspirational, e.g. the belief that US should promote democratic regimes overseas. The common good may be promoted and enforced by the state, but this is not necessarily the case. Indeed, often the core values are promoted by informal social controls, by peer pressures, and by communities.

Particularly important and challenging is the observation that references to the common good should be read as if the emphasis is on the "common" and not on the "good". For the following discussion, the main issue is whether a value is widely shared and institutionalized - not whether a particular ethicist would judge it to be morally good. Thus, for example, a society may define as a common good giving precedence to economic development over political development—or expect that all members adhere to a particular religion. Many may not consider it a good society, but it is the good the given society has formulated as its common good.

Several scholars made strong arguments against the kind of balancing approach here followed. They argue that rights are a common good, and that hence the very opposition of the two goods-rights and the common good-- the balancing analysis presupposes, is a false one. This view is held particularly with regard to freedom of speech, taking inspiration from Justice Holmes' dissent in Abrams v. United States $(1919)^{16}$ that the "ultimate good," both for the individual and society, is "better reached by free trade in ideas." It is expressed in the FCC's opinion that "the public interest is best served by permitting free expression of views." Likewise, Scott Cummings points out that many believe that "strong protection for individual rights is itself advancing the public interest ${ }^{17}$

\footnotetext{
${ }^{16}$ Abrams v. United States, 250 U.S. 616 (1919)

${ }^{17}$ Private conversation with Scott L. Cummings
}

Revista do Direito [ISSN 1982-9957]. Santa Cruz do Sul, v. 2, n. 49, p. 46-69, maio/ago. 2016. https://online.unisc.br/seer/index.php/direito/index 
At first, it may seem that one can resolve this issue by granting that common goods are a right. For instance, instead of referring to security as a common good, one can recognize a right to be safe, or a right to life. ${ }^{18}$ However, such redefinition does not vacate or obviate the balancing question. It merely moves it from asking about the balance between a good and a right to-the balance between adhering to two rights that command different pubic policies and behaviors. One can speak about the difference between what the right to privacy and the right to safety call for, but this change in wording leaving standing the question toward which right the nation is titling in a given period, and where it ought to tilt.

One next notes that many common goods are not recognized as rights either in the US constitution or the Universal Declaration of Human Rights. There is no right to national parks, historical preservation, or public health, or basic research. One can of course aspire to add these rights, but until they are recognized as such, one best not dismiss the normative claims for these goods because they are "merely" common goods and not individual rights.

Last but not least, some common goods cannot be reasonably defined as individual rights. The National Archive in Washington DC houses the original copy of the Constitution. There is a clear common good. However, to argue that individual Americans have a right to have the constitution preserved is stretching the concept of right to the point it becomes meaningless and has no foundation either in American core normative concepts nor legal traditions.

The following application of the liberal communitarian balancing approach to the analysis of the balancing of individual rights and the common good in three major area of law-free speech, public safety, and eminent domain-provides an opportunity to test the suggestion that this mode of analysis is quite productive.

\section{FREE SPEECH: SURPRISING HOMAGE TO THE COMMON GOOD}

There is a rather wide consensus that the U.S. Supreme Court has tilted heavily in favor of the right to free speech, and showed little concern for the common good (other than the common good free speech itself engenders) when serving it entails curbing free speech. The U.S. legal and normative commitment to free speech is considered one of the strongest in the world. The text of the First Amendment, which enshrines this right, reads unequivocally that "Congress shall make no law ... abridging the freedom of speech."19 The U.S. tolerates hate speech that several other democracies have banned, such as holocaust denial, racist speech, and fascist speech, and the Supreme Court has generally overturned laws that ban speech based on its hateful or otherwise distasteful content. ${ }^{20}$ The Supreme Court has also set an extremely high bar on restricting speech based on its advocacy of

\footnotetext{
${ }^{18}$ See Amitai Etzioni, Security First (New Haven: Yale University Press, 2007), 5-7

${ }^{19}$ U.S. Const. amend. I

${ }^{20}$ See, for example R.A.V. v. City of St. Paul, 505 U.S. 377, 112 S. Ct. 2538, 120 L. Ed. 2 d 305 (1992); Snyder v.

Phelps, 562 U.S. (2011); United States v. Stevens, 559 U.S. 460, 130 S.Ct. 1577 (2010)
}

Revista do Direito [ISSN 1982-9957]. Santa Cruz do Sul, v. 2, n. 49, p. 46-69, maio/ago. 2016. https://online.unisc.br/seer/index.php/direito/index 
violence or illegality; such speech must be likely to cause "imminent lawless action" to lose First Amendment protection. ${ }^{21}$ Almost no speech clears this bar, in the Court's view.

True, this strong interpretation of the First Amendment was gained only in the 1920s, following the founding of the American Civil Liberties Union (ACLU) and the influential dissents of Justices Oliver Wendell Holmes and Louis D. Brandeis in Abrams v. U.S., which eventually convinced the Court majority to adopt much stricter standards for legal restrictions on speech. ${ }^{22}$ Previously, the Court had been much more communitarian in this matter. This is evident in cases such as Rosen v. United States (upholding a conviction for mailing "obscene" material), ${ }^{23}$ Schenck v. U. S. (upholding a conviction for criticizing the draft), ${ }^{24}$ and Abrams v. U. S. (upholding a conviction for criticizing war production), ${ }^{25}$ which permitted significant content-based restrictions on speech. However, beginning in the 1920s, the Court became a very strong defender of the right to free speech. And this right was extended in in Brandenburg v. Ohio (1969) to permit "advocacy of the use of force or of law violation" unless likely to incite "imminent lawless action," ${ }^{26}$ and extended further in Hess v. Indiana (1973), to permit speech with a "tendency to lead to violence" unless "intended to produce, and likely to produce, imminent disorder." 27 Other rights-broadening rulings included National Socialist Party of America v. Village of Skokie (requiring "strict procedural safeguards" to for a state to obstruct a neo-Nazi march in a neighborhood of Holocaust survivors); ${ }^{28}$ Texas v. Johnson (allowing flag burning); ${ }^{29}$ Snyder v. Phelps (ruling speech on a public issue in a public place not liable to a tort of emotional distress, even if "outrageous" in content and context); ${ }^{30}$ and McCullen v. Coakley (invalidating a "buffer zone" against protests near an abortion clinic). ${ }^{31}$

At first blush, one may argue that the 1973 ruling about obscenity in Miller v. California, ${ }^{32}$ laid out clear content-based guidelines about impermissible speech, and hence shows that the Court in this area was willing to accord great weight to what it perceived as a common good. However, in practice, obscenity laws are "rarely enforced and widely ignored," 33 not least due to the vagueness of parts of the Miller test. Similarly, having determined in Chaplinsky v. New Hampshire $(1942)^{34}$ that $^{3}$ "fighting words" that provoke violent retaliation are not protected by the First Amendment, the Court

\footnotetext{
${ }^{21}$ Brandenburg v. Ohio, 395 U.S. 444 (1969)

${ }^{22}$ See, for example "Freedom of Expression," American Civil Liberties Union, October 31, 2005, accessed at https://www.aclu.org/free-speech/freedom-expression

${ }^{23}$ Rosen v. United States, 161 U.S. 29 (1896)

${ }^{24}$ Schenck v. United States, 249 U.S. 47 (1919)

${ }^{25}$ Abrams v. United States, 250 U.S. 616 (1919)

${ }^{26}$ Brandenburg v. Ohio, 395 U.S. 444 (1969)

${ }^{27}$ Hess v. Indiana, 414 U.S. 105 (1973)

${ }^{28}$ National Socialist Party of America v. Village of Skokie, 432 U.S. 43 (1977)

${ }^{29}$ Texas v. Johnson, 491 U.S. 397 (1989)

${ }^{30}$ Snyder v. Phelps, 562 U.S. ___ (2011)

${ }^{31}$ McCullen v. Coakley, 573 U.S. _ (2014)

${ }^{32}$ Miller v. California, 413 U.S. 15 (1973)

${ }^{33}$ Michael J. Gray, Applying Nuisance Law to Internet Obscenity, 6:2 Journal of Law and Policy for the Information Society 317, (2010)

${ }^{34}$ Chaplinsky v. New Hampshire, 315 U.S. 568 (1942)
} 
proceeded to weaken that ruling in subsequent decisions and has not found any speech to qualify as fighting words in the cases that followed. ${ }^{35}$

As for the incitement or advocacy of violence, while the Court upheld in Whitney v. California $(1927)^{36}$ the prohibition of speech threatening to "incite to crime, disturb the public peace, or threaten [the] overthrow [of government] by unlawful means," it overturned that standard in Brandenburg v. Ohio (1969), ${ }^{37}$ interpreting the "clear and present danger" standard for unprotected speech of Schenck v. United States (1919) ${ }^{38}$ as limited to that likely and intended to produce "imminent lawless action." As the concurrence acknowledged, such a standard only applies in very "rare instances." The bar for finding that speech constitutes such incitement has been set so high that the prosecution finds it next to impossible to clear it, and thus serves as a powerful speech protection, particularly given that the Court upheld this protection in subsequent cases. ${ }^{39}$ One notable exception has been in terrorism cases, where the Brandenburg test has been bypassed or applied by lower courts on shaky grounds, ${ }^{40}$ and where the Supreme Court held that material support for terrorist organizations through forms of speech such as legal services and advice, is not protected by the First Amendment. ${ }^{41}$

At first it may seem that the Court's upholding of laws against child pornography is a major exception to its very strong protection of free speech. However, it is important to note that, even in the case of such a popularly detested ${ }^{42}$ form of speech, the Court justified its restrictions on child pornography not with reference to the harm associated with viewing or distributing child pornography to the moral fabric of society or to the debasement of the culture, but rather to the specific harm inflicted on children as actors who play a role in its production! Thus, in New York v. Ferber (1982), ${ }^{43}$ the Court upheld a statute banning child pornography on the basis that the "prevention of sexual exploitation and abuse of children constitutes a government objective of surpassing importance," and in Osborne v. Ohio (1990), ${ }^{44}$ the Court upheld a ban on the mere possession of child pornography, first of all, on the basis of "compelling interests in protecting the physical and psychological wellbeing of minors."

Moreover, the Court explicitly denied in Osborne any "paternalistic interest in regulating [the] mind" for fear that obscenity would poison the minds of its viewers," and it made clear in Ferber that its ruling was limited to "live performances and photographic reproductions," not all child pornography per

\footnotetext{
${ }^{35}$ See for example Terminiello v. City of Chicago, 337 U.S. 1 (1949); Cohen v. California, 403 U.S. 15 (1971); Gooding v. Wilson 405 U.S. 518 (1972); see also David L. Hudson Jr., Fighting words, First Amendment Center, November 5, 2003

${ }^{36}$ Whitney v. California, 274 U.S. 357 (1927)

${ }^{37}$ Brandenburg v. Ohio, 395 U.S. 444 (1969)

${ }^{38}$ Schenck v. United States, 249 U.S. 47 (1919)

${ }^{39}$ See for example Hess v. Indiana, 414 U.S. 105 (1973); Communist Party of Indiana v. Whitcomb, 414 U.S. 441 (1974); National Association for the Advancement of Colored People v. Claiborne Hardware Co., 458 U. S. 886 (1982); Texas v. Johnson, 491 U.S. 397 (1989)

${ }^{40}$ See eg United States v. Rahman 189 F.3d 88; Thomas Healy, Brandenburg In A Time Of Terror, 84:2Notre Dame L. Rev. 655

${ }^{41}$ Holder v. Humanitarian Law Project, 561 U.S. 1 (2010)

${ }^{42}$ See for example Daniel P. Mears et al, Sex Crimes, Children, and Pornography: Public Views and Public Policy, 54:4 Crime and Delinquency 532 (2008) accessed at http://cad.sagepub.com/content/54/4/532.full.pdf+html

${ }^{43}$ New York v. Ferber, 458 U.S. 747 (1982)

${ }^{44}$ Osborne v. Ohio, 495 U.S. 103 (1990)
} 
se. This distinction was affirmed in Ashcroft v. Free Speech Coalition (2002), ${ }^{45}$ when the Court held that a ban on virtual child (that is, not involving real children) pornography was "overbroad and unconstitutional" as it "also prohibits speech having serious redeeming value." In short, the Court's rulings have sought to limit child pornography as employment, not as speech issue. Even here the Court refused to limit speech to defend a common good, however good it may seem to many people.

This paper will not deal with the Court's rulings on libel and defamation, as these forms of speech are disputed mainly on the basis of harm to individuals rather than to the common good. It also does not cover the Court's treatment of money used in election campaigns as speech because the rulings involved raise such a great number of other issues that they commands a separate treatment.

Given the Court's very strong defense of free speech in the contentious areas of obscenity, provocation, and incitement, not found in other democracies, one might conclude that the Court has little regard for public interests in this area, and takes an absolutist approach to free speech rights. Indeed, this is a position often articulated both in public discourse and in the academy. Some find that the "absolutist free speech model in the United States" is "foundationally very different and much more protective of liberty [...] than those of Europe or Canada, ${ }^{46}$ while others bemoan the "absolutist' position" and "ideological refusal to acknowledge [the] dangerous implications for the growth of hate speech." ${ }^{47}$ However, we find that the Court has taken a surprisingly communitarian position in one area-in greatly limiting the time, place, and manner (TPM) of speech, in order to serve a variety of communitarian interests that do not command nearly as much normative standing as avoiding violence, inter group hatred, or degrading the moral culture.

Thus, the Court upheld Los Angeles' ban on posting fliers on public property, given the city's interests in "preventing visual clutter, minimizing traffic hazards, and preventing interference with the intended use of public property." 48 It upheld permit requirements that limit marches on public streets in order to protect "public convenience" 49 rather than speech. Other relevant cases concern those in which the Court upheld a ban on sound trucks that emit "loud and raucous noises" given the "need for reasonable protection in the homes or business houses from the distracting noises," on noisy protests on school grounds on the basis of "compelling interest in having an undisrupted school session." ${ }^{.51}$ And, it upheld a statute forcing performers to use government-provided sound equipment and technicians to ensure that performances in a certain venue were not too loud. ${ }^{52}$

Many other TPM rulings limit speech to provide noise controls. For example, the Court upheld a ban on picketing outside residential homes in order to protect the "wellbeing, tranquility, and privacy of the home," an "important aspect" of which is "the protection of unwilling listeners [...] from the

\footnotetext{
${ }^{45}$ Ashcroft v. Free Speech Coalition, 535 U.S. 234 (2002)

46 James M. Boland, Is Free Speech Compatible with Human Dignity, Equality, and Democratic Government: America, a Free Speech Island in a Sea of Censorship?, 6:1 Drexel L. Rev. 1, accessed at http://drexel.edu/law/lawreview/

47 John D.H. Downing, 'Hate Speech' and 'First Amendment Absolutism' Discourses in the US, 10:2 Discourse 175 (1999)

${ }^{48}$ Members of City Council of Los Angeles v. Taxpayers for Vincent, 466 U.S. 789, 801 (1984)

${ }^{49}$ Cox v. New Hampshire, 312 U.S. 569 (1941)

${ }^{50}$ Kovacs v. Cooper, 336 U.S. 77 (1949)

${ }^{51} 408$ U.S. 104 Grayned v. City of Rockford

52491 U.S. 781 Ward v. Rock Against Racism
}

Revista do Direito [ISSN 1982-9957]. Santa Cruz do Sul, v. 2, n. 49, p. 46-69, maio/ago. 2016. https://online.unisc.br/seer/index.php/direito/index 
intrusion of objectionable or unwanted speech. ${ }^{, 53}$ That is of course the kind of speech champions of the First Amendment hold is which most protecting.

The Court has been willing, consistently, to limit speech for common goods that may be justified but command less of a standing in the society's scale of values as those it left almost completely unprotected.

One may argue that the Court found it much easier to limit speech causes served by TPM limitations on speech because these restrictions are content neutral, while to serve other causes might well entail limiting speeches of one kind of content (e.g. radical) and not others (e.g. moderate). However, Britain, Canada, Denmark, Sweden, France, Germany, and Australia are among the nations that were able to set such content-based limits, and still free speech thrives in these countries and they are considered solid democracies. Moreover, American society has erected strong taboos against select terms and symbols, for instance the $\mathrm{N}$ word, leading to firing of news anchors and benching of sport stars if they use it, illustrating that one can draw a content line without this sliding down a slippery slope of censorship or otherwise suppressing free speech.

In short, it seems quite clear that the Court is willing to allow the most profound sensibilities of the majority of Americans to be offended (e.g. by flag burning); let their emotions and values be assaulted (e.g. when their bury their fallen soldiers ); tolerate speech that promotes hate in the most vile terms, and even allow speech that may well incite violence or riots-but ban speech that may disrupt the slumber of some suburbanites or upset the tranquility of the downtown business community. Instead of being particularly uncommunitarian when it comes to free speech, by greatly privileging this right, the Court showed itself repeatedly to be willing to curb speech for relatively light common goods and not for the weightiest ones.

\section{PUBLIC SAFETY: UNCLEAR BUT PRESENT BALANCE}

A review of Supreme Court rulings shows that the Court has a broad understanding of public safety that allows diverse intrusions into the realm of individual rights to serve this common good. The most basic element of public safety is upholding of law and order, the deterrence and prevention of crime (Many cases in point are cited below). A second element of public safety relates to preventing accidental death and injury. Thus, the Court allowed suspicion less random drug and alcohol testing of train engineers in the wake of a series of train accidents, ${ }^{54}$ as well as random sobriety checkpoints on highways to prevent deadly car accidents resulting from drunk driving. ${ }^{55} \mathrm{~A}$ third element of public safety is the promotion of public health. Thus, the Court held that the public interest in eradicating the smallpox disease justified compulsory vaccination programs, ${ }^{56}$ despite the resulting intrusion on

\footnotetext{
${ }^{53}$ Frisby v. Schultz, 487 U.S. 474 (1988)

${ }^{54}$ Skinner v. Railway Labor Executives' Association 489 U.S. 602

${ }^{55}$ Michigan Dept. of State Police v. Sitz, 496 U.S. 444 (1990)

${ }^{56}$ Jacobson v. Massachusetts, 197 U.S. 11 (1905)
} 
privacy, and held that search warrants for Occupational Safety and Health Act (OSHA) inspections do not require "probable cause in the criminal law sense." 57

Another element is the promotion of national security and counterterrorism. This element is not encompassed in this examination because of great differences between this public good and the others under study.

In seeking to determine where to draw the communitarian balance in this area, the Court very often draws on the Fourth Amendment. This Amendment captures well the basic thesis of the liberal communitarian way of thinking. By banning only unreasonable searches and seizures ${ }^{58}$ the Fourth Amendment recognizes, on the face of it, a category of reasonable searches, which turn out typically to be those that promote public safety and do not require a warrant or probable cause. That is, the very text speaks of two sides, and hence of a balance, in sharp contrast to the First Amendment, which states "Congress shall make no law [...] abridging the freedom of speech." ${ }^{59}$

Finally, disregarding those who oppose the very notion of balancing, ${ }^{60}$ the Court determines whether searches are reasonable through "the balancing of competing interests," which the Court views as the "key principle of the Fourth Amendment." quality of the intrusion on the individual's Fourth Amendment interests against the importance of the governmental interests alleged to justify the intrusion"62 to determine whether "the totality of the circumstances justified a particular sort of search or seizure."63 The Fourth Amendment is thus a liberal communitarian text par excellence.

In seeking the point of balance between individual rights and public safety, the Court has used a variety of criteria, each with its own rationale. The result is a complex, difficult, and at times wavering or inconsistent approach. Thus, the Court adopted in 1948 the "cardinal rule that, in seizing goods and articles, law enforcement agents must secure and use search warrants wherever reasonably practicable," ${ }^{\prime 64}$ only to assert two years later, following the appointment of new justices, that the "relevant test is not whether it is reasonable to procure a search warrant, but whether the search was reasonable" based on "the facts and circumstances of each case." The following review of several of the Court's key positions on public safety reveals that in a considerable number of cases, the Court places a high value on public safety when balanced against individual rights. The review strictly aims to support conclusion rather than attempt to provide a comprehensive review of all or even most relevant cases.

\footnotetext{
${ }^{57}$ Marshall v. Barlow's, Inc. 436 U.S. 307 (1978)

58 U.S. Const., amend. IV.

${ }^{59}$ U.S. Const., amend. I.

${ }^{60}$ See for example Justice Scalia's criticism of the balancing test in his dissent in Bendix Autolite Corp. v. Midwesco Enterprises, 486 U.S. 888 (1988) (the "scale analogy is not really appropriate since the interests on both sides are incommensurate. It is more like judging whether a particular line is longer than a particular rock is heavy.")

${ }^{61}$ Michigan v. Summers, 452 U.S. 692, 700 , n. 12 (1981)

62 United States v. Place, 462 U.S. 696, 703 (1983)

${ }^{63}$ Tennessee v. Garner, 471 U.S. 1 (1985)

${ }^{64}$ Trupiano v. United States 334 U.S. 699 (1948)
}

Revista do Direito [ISSN 1982-9957]. Santa Cruz do Sul, v. 2, n. 49, p. 46-69, maio/ago. 2016. https://online.unisc.br/seer/index.php/direito/index 


\section{Exigent Circumstances}

One criterion used by the Court to balance public safety and individual rights is the presence of "exigent circumstances" that make a warrantless search or seizure "imperative," for instance, when an emergency creates an urgent need for police to act. ${ }^{65}$ The Court has held such emergencies to include the pursuit of a fleeing suspect, the imminent destruction of evidence, and the "need to protect or preserve life or avoid serious injury." ${ }^{, 66}$

Two cases illustrate this criterion. In Warden v. Hayden (1967), ${ }^{67}$ the Court upheld the warrantless entry of police into a private house to pursue a fleeing armed robbery suspect, on the ground that to "require police officers to delay in the course of an investigation" might "gravely endanger their lives or the lives of others." Having concluded the search was reasonable, the Court also rejected the broader principle that police may only search a home for, and seize, evidence in which the state has some property interest (such as stolen goods), holding instead that searches for "mere evidence" of a crime do not violate constitutional protections against self-incrimination. Thus, the Court qualified both the Fourth and Fifth Amendments in order to promote public safety.

In Kentucky v. King (2011), ${ }^{68}$ the Court upheld the warrantless entry of police into an apartment after officers smelled marijuana, knocked on the door, and heard what they suspected to be the destruction of evidence. In this case, the Court held that "exigent circumstances-the need to prevent destruction of evidence-justified the warrantless entry," despite the fact the police "created" the exigent circumstance by knocking on the door, because the knock itself did not constitute a violation of the Fourth Amendment. (Although cases such as this one have broadened the exigent circumstances exception, it should be noted that exigent circumstances are in general narrowly defined. ${ }^{69}$ The Court refuses to apply this exception when the timing of a search is not urgent or the "gravity of the underlying offense" is minor. ${ }^{70}$ Thus, in Welsh v. Wisconsin, the Court held that suspicion of drunk driving did not constitute an exigent circumstance justifying warrantless police entry into the suspect's home to arrest him.

\section{Special Needs and Administrative Searches}

In seeking criteria to ferret out the liberal communitarian balance, the Court carved out a very large category of exceptions to the need for individualized suspicion and Court approval, namely

\footnotetext{
${ }^{65}$ McDonald v. United States 335 U.S. 451 (1948)

${ }^{66}$ The court summarized this position in Brigham City v. Stuart, 547 U.S. 398 (2006)

${ }^{67}$ Warden v. Hayden 387 U.S. 294 (1967)

${ }^{68}$ Kentucky v. King, 563 U.S. ___ (2011)

${ }^{69}$ See for example Coolidge v. New Hampshire, 403 U.S. 443 (1971)(“searches conducted outside the judicial process, without prior approval by judge or magistrate, are per se unreasonable under the Fourth Amendment-subject only to a few specifically established and well delineated exceptions. The exceptions are 'jealously and carefully drawn,' and there must be 'a showing by those who seek exemption that the exigencies of the situation made that course imperative. (T)he burden is on those seeking the exemption to show the need for it.") (citations removed)

${ }^{70}$ Welsh v. Wisconsin 466 U.S. 740 (1984) (ruling that the need to perform a blood test on a suspected drunk driver did not constitute an exigent circumstance justifying warrantless entry into a private home)
}

Revista do Direito [ISSN 1982-9957]. Santa Cruz do Sul, v. 2, n. 49, p. 46-69, maio/ago. 2016. https://online.unisc.br/seer/index.php/direito/index 
administrative searches that are justified by "special needs beyond the normal need for law enforcement." Most deal with searches that do not involve criminal investigations, for instance, routine inspections by personnel from the Occupational Safety and Health Administration. The category also includes warrantless searches by administrative authorities in public schools, government offices, and prisons; drug testing of public transportation and other government employees; and inspection of automobile junkyards and dismantling operations.

In all of these cases "the warrant and probable cause requirements are dispensed with in favor of a reasonableness standard that balances the government's regulatory interest against the individual's privacy interest; in all of these instances the government's interest has been found to outweigh the individual's."71

A key precedent for the "special needs" exception is Skinner v. Railway Lab. Execs. Ass'n (1989), ${ }^{72}$ where the Court allowed suspicion less, warrantless drug and alcohol testing of train engineers in the wake of a series of train accidents. In that case, the Court held that, while such tests do constitute searches under the Fourth Amendment, they are "reasonable" searches because the government's "compelling" interest in ensuring "the safety of the traveling public" outweighs the employees' privacy concerns.

Similar considerations affected the Court's ruling in Michigan Dept. of State Police v. Sitz (1990), ${ }^{73}$ which upheld warrantless sobriety tests at random highways checkpoints. In that case, while acknowledging that checkpoint stops constitute a "seizure" under the Fourth Amendment, the Court denied the respondents' argument that such stops failed to serve a "special need." Instead, the Court pointed to the "magnitude of the drunken driving problem [and] the States' interest in eradicating it," as well as the Court's approval of similar checkpoints to search for illegal immigrants in United States v. Martinez-Fuerte (1976) ${ }^{74}$. Applying a balancing test, the Court found the privacy intrusion of sobriety checkpoint stops to be small and the effectiveness of the program to be adequate.

For those who are not tutored in the law, the author included, this special needs' category could be divided into several subcategories that seem reasonable. In one, the acts of those subject to search without judicial review are those can directly and significantly endanger the lives of others, e.g. train engineers. "Directly and significantly" is added to limit this subcategory because a very large number of people have some effect on the probability that someone will be hurt. Another sub category is where enforcement is regulatory and cannot results in criminal charges, for instance ensuring that restaurant workers maintain safe food handling practices and personal hygiene. A third subcategory is when it is not practical to seek a warrant because a very large number of people needs to be searched in short order. One example of this is when the police set up sobriety checkpoints on New Year's Eve. Another is the screening gates first introduced into US airports in 1972, which stopped sky jacking

\footnotetext{
${ }^{71}$ Annotation 1 - Fourth Amendment Search and Seizure, Findlaw for Legal Professionals, 2014, accessed at http://constitution.findlaw.com/amendment4/annotation01.html

72 Skinner v. Railway Lab. Execs. Ass'n 489 U.S. 602 (1989)

${ }^{73}$ Michigan Dept. of State Police v. Sitz, 496 U.S. 444 (1990)

${ }^{74}$ United States v. Martinez-Fuerte, 428 U.S. 543, 567 (1976)
}

Revista do Direito [ISSN 1982-9957]. Santa Cruz do Sul, v. 2, n. 49, p. 46-69, maio/ago. 2016. https://online.unisc.br/seer/index.php/direito/index 
effectively but were challenged by the ACLU. ${ }^{75}$ In all these kinds of case, the Court privileged the common good over privacy.

\section{Consent}

A third criterion used by the Court to balance public safety and individual rights is the presence of consent. Simply put, individuals are free to waive their Fourth Amendment protection against warrantless searches and seizures by consenting to the search or seizure in question. At first blush, one may think that this criterion does not affect the balance because consent is willingly granted. However, many people are not aware of their right to refuse to consent. In contrast to the Fifth Amendment's Miranda warning requirement, the Court held that police do not need to inform an individual of their right to refuse consent to a search or seizure. ${ }^{76}$ Moreover, authority to consent may be shared among multiple individuals (for instance, among roommates) with only the consent of one required for police to search. In dealing with such questions, the Court's rulings reveal that even in this matter the Court has tended to favor the public interest over individual rights. Thus, the Court held that consent to a search of joint property may be given by either resident in the other's absence, ${ }^{77}$ though if both owners are present, either may refuse consent. ${ }^{78}$ Even the latter limitation on the consent exception is qualified by the fact that police may still enter a shared home if they suspect domestic violence to have occurred. (Somewhat offsetting these tilts towards the public safety, the Court does limit the consent exception by holding that burden of proof is on the prosecution to prove that consent was given freely and not under coercion). ${ }^{79}$

\section{Intrusiveness}

A fourth criterion used by the Court draws on the extent individual rights are intruded upon than on the weight accorded to the specific public interest involved, drawing on concerns about the level of intrusiveness engendered by a given search or seizure. Put another way, the Court is more likely to consider upholding a warrant exception for a search or seizure-whatever the common good-if the government action is minimally intrusive. Thus, in reference to seizure of a suspected container of illegal drugs, the Court articulated that "seizures of property can vary in intrusiveness," and "when the nature and extent of the detention are minimally intrusive of the individual's Fourth

\footnotetext{
${ }^{75}$ See for example Civil Liberties Implications of Airport Security Measures: Hearing Before White $\mathrm{H}$. Comm. in Aviation Safety and Security, (1996) (statement of Gregory T. Nojeim, Legis. Counsel, American Civil Liberties Union); see also Am. Civil Liberties Union, Airport Security: Increased Safety Need Not Come At The Expense Of Civil Liberties (2002), accessed at https://www.aclu.org/national-security/airportsecurityincreased-safety-need-not-come-expense-civil-liberties

${ }^{76}$ Schneckloth v. Bustamonte 412 U.S. 218 (1973)

${ }^{77}$ United States v. Matlock 415 U.S. 164 (1974)

${ }^{78}$ Georgia v. Randolph, 547 U.S. 103 (2006)

${ }^{79}$ Bumper V. North Carolina, 391 U.s. 543 (1968)
} 
Amendment interests, the opposing law enforcement interests can support a seizure based on less than probable cause., ${ }^{80}$

Two examples illustrate the role of the level of intrusiveness in the Court's Fourth Amendment balancing. On the one hand, in Maryland v. King (2013), ${ }^{81}$ the Court upheld compulsory DNA sampling of those arrested based on probable cause of serious crimes, in large part due to the limited intrusiveness of the search. Having already concluded that the public safety interest in identifying suspects was great and that DNA sampling significantly furthered that interest-the Court went on to argue that the "intrusion of a cheek swab to obtain a DNA sample is minimal" as it involves "virtually no risk, trauma, or pain," and furthermore that police DNA databases do "not intrude on [...] privacy in a way that would make [such] DNA identification unconstitutional." The Court held this finding that the intrusion was "negligible" to be of "central relevance to determining reasonableness."

On the other end of this scale, the Court held in Tennessee v. Garner (1985), ${ }^{82}$ largely on the basis of level of intrusiveness, that use of deadly force against an unarmed, fleeing burglary suspect was unconstitutional. In this case, the Court acknowledged that "burglary is a serious crime" and that police had probable cause to arrest the suspect. However, given that the "intrusiveness of a seizure by means of deadly force is unmatched," it ruled the seizure to be unconstitutional (rejecting the argument that killing the suspect would make other suspects more likely to surrender). Note, however, that the Court did not rule out the use of deadly force entirely, but instead limited it to situations where "the officer has probable cause to believe that the suspect poses a significant threat of death or serious physical injury," thus avoiding excessive harm to public safety interests.

\section{Expectation of privacy}

A fifth criterion used by the Court is the expectation of privacy, which to a significant extent tilts in favor of the individual rights' side of the communitarian equation. The Court's analysis of privacy expectations originates in its ruling in Katz v. United States (1967), ${ }^{83}$ which held that although what "what a person knowingly exposes to the public" is not protected by the Fourth Amendment"- "what he seeks to preserve as private, even in an area accessible to the public" may be protected as long as the person exhibits a subjective expectation of privacy that society recognizes as "reasonable." Since then, the Katz test has been criticized for being circular and subjective, and for leading to mixed results in Fourth Amendment cases. ${ }^{84}$ For the purposes of this discussion, it suffices to point out that the Court's evaluation of specific privacy expectations has favored the public interest in several key cases.

One notable example is found in California v. Greenwood, where the Court held that the Fourth Amendment does not protect against warrantless search and seizure of garbage left outside

\footnotetext{
${ }^{80}$ United States v. Place, 462 U.S. 696 (1983)

${ }^{81}$ Maryland v. King, 569 U.S. ___ (2013)

${ }^{82}$ Tennessee v. Garner 471 U.S. 1 (1985)

${ }^{83}$ Katz v. United States 389 U.S. 347 (1967)

${ }^{84}$ Amitai Etzioni, Eight Nails into Katz's Coffin, 65:2 Case W. Res. L. Rev. (forthcoming 2015) accessed at http://papers.ssrn.com/sol3/papers.cfm?abstract_id=2506312
} 
the home, which had been conducted by the police to support a search warrant for a drug raid on a nearby house. In this ruling, the Court argued that an expectation of privacy in items discarded "in an area particularly suited for public inspection" is "not objectively reasonable." 85

Also, the Court held in Smith v. Maryland (1979) that the tracking by a phone company (at police request) of phone numbers dialed by a suspect did not constitute a "search" under the Fourth Amendment. In this ruling, the Court held that the suspect "in all probability entertained no actual expectation of privacy" in his calling records, and such an expectation would not have been "legitimate," given that telephone users "typically know [...] that the company has facilities for recording this information and does, in fact, record it for various legitimate business purposes." ${ }^{86}$ This case set an important precedent for the "third party doctrine," which holds that information shared with third parties is not protected by the Fourth Amendment. ${ }^{87}$ As advances in information technology have led third parties to play an increasingly important role in storing and transmitting otherwise confidential information, this doctrine increasingly privileges the public interest side of the communitarian equation by facilitating law enforcement access to personal information.

\section{Additional considerations}

The five criteria listed above are not a comprehensive list of factors considered by the Court in balancing public safety and individual rights. In its extensive Fourth Amendment jurisprudence, the Court has formulated several other specific exceptions and qualifications to the Fourth Amendment warrant, probable cause, and individualized suspicion requirements-and provided additional rationale for so ruling. Thus, the Court held that warrantless searches of automobiles are permitted given probable cause ${ }^{88}$ that searches at international borders require neither warrants nor probable cause, ${ }^{89}$ and that that evidence in "plain view" during a legitimate search may be seized, ${ }^{90}$ giving different rationales in each case, although some partially overlap with those already cited above.

Some argue that the Court's rulings over the last few decades have steadily undermined individual rights, particularly privacy, by favoring public safety considerations in Fourth Amendment cases. Thus, Thomas N. McInnis argues that the Court's changing interpretations of the amendment have eroded the warrant requirement over time. William Stuntz finds that the Court's change of emphasis in focusing on "unreasonable searches and seizures" rather than the warrant clause has narrowed the scope of the warrant requirement. Andrew Talai holds that, "in the last few decades, the Supreme Court has narrowed its vision of Fourth Amendment rights to an opaque privacy rationale." Shaun Spencer states that changing technology, coupled with the Court's "reasonable expectations" doctrine of privacy, facilitates the incremental erosion of privacy. Likewise, Shima Baradaran notes that the Court has tended to favor the government when balancing individual rights and public safety

\footnotetext{
${ }^{85}$ California v. Greenwood 486 U.S. 35 (1988)

${ }^{86}$ Smith v. Maryland 442 U.S. 735 (1979)

${ }^{87}$ See for example Orin S. Kerr, The Case for the Third-Party Doctrine 107:4 Mich. L. Rev. 561 (2009)

${ }^{88}$ Carroll v. United States, 267 U.S. 132 (1925)

${ }^{89}$ U.S. v. Ramsey, 431 U.S. 606 (1977)

${ }^{90}$ See for example Horton v. California 496 U.S. 128 (1990)
} 
in recent Fourth Amendment cases because the Fourth Amendment case is typically made by a "criminal defendant whose hands are dirty." For his part, Christopher Slobogin argues that the Court's Fourth Amendment jurisprudence has failed to keep pace with evolving government surveillance techniques. $^{91}$

At the same time, no one claims that all the cases lined up on one side of liberal communitarian balancing equation. Any such trend is offset in part by two factors: the Court's restricting warrantless searches in recent cases, and its creation of new rights. The Court has introduced and clarified new rights though mainly in the 1960s. The Court introduced the Miranda right, ${ }^{92}$ and the reasonable expectation of privacy standard, which, for all its limits, has upheld individual rights against public safety concerns in contexts where a different Fourth Amendment doctrine might not have, as with thermal imaging ${ }^{93}$ and use of drug-sniffing dogs ${ }^{94}$ on the periphery of a house.

More recently, in Riley v. California $(2014)^{95}$ the Court limited the warrant exception for searches incident to a lawless arrest by affirming that police searches of arrestees' cell phone data require a warrant. The Court also limited the privacy expectations doctrine in U.S. v. Jones, ${ }^{96}$ holding that surreptitious police attachment of a GPS surveillance device to a suspect's car violated his Fourth Amendment property rights, thus constituting a "search" regardless of privacy expectations. Commentators have argued that Riley and Jones, respectively, "brought the Fourth Amendment into the digital age ${ }^{, 97}$ and "bode well for continued protection of citizens' public privacy rights.,"98

In short, whether one finds that the Court has found a sound liberal communitarian balance, or that it has tilted too heavily toward either the public safety or the individual rights side of the balancing equation, there is no question that the Court accorded considerable weight to the public interest.

\footnotetext{
${ }^{91}$ The Evolution of the Fourth Amendment Thomas N. McInnis Lexington Books 2009; William J. Stuntz, Warrant Clause, Heritage Guide to the Constitution, 2012; Drones and Jones: The Fourth Amendment and Police Discretion in the Digital Age Andrew B. Talai California Law Review; Shaun B. Spencer, Reasonable Expectations and the Erosion of Privacy, 39 San Diego L. Rev. 845 (2002); Baradaran, Shima, Rebalancing the Fourth Amendment (March 21, 2013). Georgetown Law Journal, Forthcoming. Available at SSRN: http://ssrn.com/abstract=2237642; Slobogin, Christopher, Privacy at Risk: The New Government Surveillance and the Fourth Amendment. Available at SSRN: http://ssrn.com/abstract=1026614; see also Andrew J. DeFilippis, Note, Securing Informationships: Recognizing a Right to Privity in Fourth Amendment Jurisprudence, 115 Yale L.J. 1086, 1092 (2006) (criticizing the court's third party doctrine in particular for undermining privacy in a society increasingly characterized by "shared access to and exchange of personal information"); George Dery, Expedient Knocks and Cowering Citizens: The Supreme Court Enables Police to Manufacture Emergencies by Pounding on Doors at Will in Kentucky v. King, 17 Berkeley J. Crim. L. 225 (2012) (arguing that recent decisions show "a trend in Fourth Amendment precedent in which the Court has continually lowered the bar for police [intrusions]" and diminished the warrant requirement)

${ }^{92}$ Miranda v. Arizona, 384 U.S. 436 (1966)

${ }^{93}$ Kyllo v. United States, 533 U.S. 27 (2001)

${ }^{94}$ Florida v. Jardines, 569 U.S. _ (2013)

${ }^{95}$ Riley v. California, 573 U.S. _ (2014)

${ }^{96}$ United States v. Jones 565 U.S. _ (2012)

${ }^{97}$ Marc Rotenberg and Alan Butler, Symposium: In Riley v. California, a unanimous Supreme Court sets out Fourth Amendment for digital age, SCOTUSblog;

${ }^{98}$ Daniel T. Pesciotta, I'm Not Dead Yet: Katz, Jones, and the Fourth Amendment in the 21st Century, 63 CASE W. RES. L. REV. 187 (2012)
}

Revista do Direito [ISSN 1982-9957]. Santa Cruz do Sul, v. 2, n. 49, p. 46-69, maio/ago. 2016. https://online.unisc.br/seer/index.php/direito/index 


\section{EMINENT DOMAIN: OPENINGS TO CAPTURE}

A third area in which we study the Supreme Court balancing of the common good and individual rights is that of eminent domain, or the expropriation of private property by the government in the service of one public interest or another. The legal concept of eminent domain is based on the Fifth Amendment takings clause, which reads, "nor shall private property be taken for public use, without just compensation." ${ }^{99}$ In 1875, the Court asserted that the clause "contains an implied recognition" of eminent domain: "[what is the] provision that private property shall not be taken for public use without just compensation [...] but an implied assertion that, on making just compensation, it may be taken?"100 As a result, the Court affirmed the Federal Government's "power to appropriate lands or other property within the states for its own uses," arguing that such power is "essential to its independent existence and perpetuity"101 and "is an attribute of sovereignty."102 The Court's subsequent rulings concerned defining what uses of confiscated property may qualify as "public use," and thus are constitutionally valid.

The Court recognized that eminent domain may be used to secure property for government buildings; water, transportation, communications, and energy infrastructure; and national defense. ${ }^{103}$ The Court also upheld the use of eminent domain for "public buildings," including "for forts, armories, and arsenals, for navy yards and lighthouses, for custom houses, post offices, and courthouses, and for other public uses." 104 Subsequent rulings affirmed that eminent domain could be used to secure land for memorial sites, ${ }^{105}$ aqueducts, ${ }^{106}$ canals, ${ }^{107}$ railroads, ${ }^{108}$ war production, ${ }^{109}$ and public parks. ${ }^{110}$

State legislatures and state and federal courts also permitted the use of eminent domain by private entities, such as canal, railroad, and turnpike companies, to build transportation infrastructure to which the public would have access, ${ }^{111}$ as well as for electricity and lighting infrastructure ${ }^{112}$ oil pipelines, ${ }^{113}$ telephone lines, ${ }^{114}$ and cable and fiber optic lines. ${ }^{115}$

\footnotetext{
${ }^{99}$ U.S. Const. amend. V

${ }^{100}$ Kohl v. United States 91 U.S. 367

${ }^{101}$ Kohl v. United States 91 U.S. 367 (1875)

102 Boom Co. v. Patterson 98 U.S. 403 (1878)

103 Ilya Somin, The Civil Rights Implications Of Eminent Domain Abuse, Testimony Before The United States Commission On Civil Rights, George Mason University, August 12 2011, accessed at http://www.law.gmu.edu/assets/files/faculty/Somin_USCCR-aug2011.pdf

${ }^{104}$ Kohl v. United States 91 U.S. 367 (1875)

105 United States v. Gettysburg Electric Ry., 160 U.S. 668, 679 (1896)

${ }^{106}$ United States v. Great Falls Manufacturing Company, 112 U.S. 645 (1884)

107 United States v. Chandler-Dunbar Co., 229 U.S. 53 (1913), see also Albert Hanson Lumber Company v. United States, 261 U.S. 581 (1923)

${ }^{108}$ See for example Hairston v. Danville \& Western Ry. Co. 208 U.S. 598 (1908)

${ }^{109}$ Sharp v. United States, 191 U.S. 341 (1903)

${ }^{110}$ Shoemaker v. United States, 147 U.S. 282 (1893)

${ }^{111}$ See for example Arnold v. Covington \& Cincinnati Bridge Co., 1 Duv. 372 (Ky. 1864); see also Kelly, Daniel B., The Public Use Requirement in Eminent Domain Law: A Rationale Based on Secret Purchases and Private Influence. Cornell Law Review, Vol. 92, No. 1, 2006.

http://www.law.harvard.edu/programs/olin_center/fellows_papers/pdf/Kelly_5.pdf

${ }^{112}$ See, e.g., City of Stillwell v. Ozark Rural Electric Cooperative Corporation, 79 F.3d 1038 (10th Cir.
} 
In Berman v. Parker $(1954)^{116}$ the Court permitted the state not only to seize property for literal "public use" (whether under private or public ownership), but also to transfer property to a new private owner for their own private use, albeit in pursuit of some broader "public purpose." Specifically, the Court found that the use eminent domain to facilitate "urban renewal" programs was a justifiable way to deal with "urban blight," or slum conditions. The Court deferred to Congress and state legislatures to determine what qualifies as a "public purpose" justifying eminent domain, upholding "all means necessary and appropriate" to deal with conditions "injurious to the public health, safety, morals, and welfare." As such, the Court upheld in Berman both the seizure of non-blighted property within a blighted area in pursuit of a comprehensive development plan, and the transfer of property to another private owner for private, rather than public, use.

The Court noted that while the government's "police power" had been traditionally associated with "public safety, public health, morality, peace and quiet, law and order," these examples "merely illustrate the scope of the power, and do not delimit it," as the "concept of the public welfare is broad and inclusive [...] The values it represents are spiritual as well as physical, aesthetic as well as monetary."117

Taking Berman as precedent, another unanimous ruling upheld a Hawaii land reform program intended to broaden land ownership, accepting the Hawaii Legislature's position that "concentrated land ownership was responsible for skewing the State's residential fee simple market, inflating land prices, and injuring the public tranquility and welfare," and reaffirming that "regulating oligopoly and the evils associated with it is a classic exercise of a State's police powers." ${ }^{118}$ In making this judgment, the Court broadened the precedent from Berman, arguing that while taking "one person's property [...] for the benefit of another [requires a] justifying public purpose [...] It is not essential that the entire community, nor even any considerable portion... directly enjoy or participate [for it] to constitute a public use."

Continuing this trend, the Court's 5-4 ruling in Kelo v. City of New London (2005) held that the government may also use eminent domain to transfer private property from one owner to another, in this case from the residents of a neighborhood to a private developer, not only to deal with blight but merely "for the purpose of economic development," with no obligation on the new owner to perform a public function or grant public access. ${ }^{119}$ The Court deferred to the "city's determination that the area at issue was sufficiently distressed to justify a program of economic rejuvenation," arguing that "because that plan unquestionably serves a public purpose, the takings challenged here satisfy the Fifth Amendment." Thus, the Court rejected the argument that "economic development does not qualify as a public use," countering that "promoting economic development is a traditional and long accepted governmental function, and there is no principled way of distinguishing it from the other

\footnotetext{
1996)

${ }^{113}$ See for example Producers Pipe Line Co. v. Martin, 22 F. Supp. 44 (W.D. Ky. 1944)

114 See, e.g., Buncombe Metallic Tel. Co. v. McGinnis, 109 N.E. 257 (III. 1915)

115 See, e.g., Cablevision of the Midwest v. Gross, 639 N.E.2d 1154 (Ohio St. 3d 1994)

${ }^{116}$ Berman v. Parker, 348 U.S. 26 (1954)

${ }^{117}$ Berman v. Parker, 348 U.S. 26 (1954)

${ }^{118}$ Hawaii Housing Authority v. Midkiff, 467 U.S. 229 (1984)

${ }^{119}$ Kelo v. City of New London, 545 U.S. 469 (2005)
} 
public purposes." Crucially, it rejected calls for "'reasonable certainty' that the expected public benefits will actually accrue" (such as a legal obligation on the developer to meet certain economic goals), noting the "departure from the Court's precedent" and "disadvantages of a heightened form of review" that such requirements would entail.

The Kelo ruling greatly weakened the safeguards against eminent domain abuse, much increasing the incentive for private interests to influence regulators, while reducing the potential for public accountability. That is not to argue that eminent domain in line with Kelo cannot serve the public interest. Defenders of Kelo point out that "residential condemnation for redevelopment" is rare, and in most states is required to produce more and better low-income housing. ${ }^{120}$ By watering down the definition of public use, however, the ruling greatly increased the risk that special interests will capture the process. Thus, Justice O'Connor, arguing for the minority, warned that the "specter of condemnation hangs over all property. Nothing is to prevent the State from replacing any Motel 6 with a Ritz-Carlton, any home with a shopping mall, or any farm with a factory [...] The beneficiaries are likely to be those citizens with disproportionate influence and power in the political process, including large corporations and development firms." Even Justice Kennedy, who concurred with the judgment, warned that courts must still strike down any taking "that, by a clear showing, is intended to favor a particular private party, with only incidental or pretextual public benefits." He argued that they should "treat the objection as [serious] and review the record to see if it has merit" when "confronted with a plausible accusation of impermissible favoritism to private parties." Finally he suggested that there "may be private transfers in which the risk of undetected impermissible favoritism of private parties is so acute that a presumption (rebuttable or otherwise) of invalidity is warranted under the Public Use Clause." ${ }^{121}$

It is important to note that the "blight" standard for eminent domain in place prior to Kelo already created opportunities for abuse, due to the broad definition of blight which critics argue includes "vague and subjective criteria" that could apply to virtually any property, ${ }^{122}$ and the permissive process for its determination (which critics allege facilitates rent-seeking and regulatory capture behavior by developers, and suffers from excessive deference by the judiciary.) ${ }^{123}$ Most notoriously, the mid-20th century urban renewal projects facilitated by Berman, while having some positive economic impact, ${ }^{124}$ are generally seen even by today's proponents of eminent domain ${ }^{125}$ to have been racially discriminatory in their motivations and impact, as they tended to displace African

\footnotetext{
${ }^{120}$ Marc B. Mihaly, "Public-Private Redevelopment Partnerships and the Supreme Court: Kelo v. City of New London,"

${ }^{121}$ Kelo v. City of New London, 545 U.S. 469 (2005)

122 Matthew Kokot, Balancing Blight:Using the Rules Versus Standards Debate to Construct a Workable Definition of Blight, 45 Colum. J.L. \& Soc. Probs. 45 (2011)

${ }^{123}$ Eric R. Claeys, Symposium, That 70's Show: Eminent Domain Reform and the Administrative Law Revolution, 46 Santa Clara L. Rev. 867 (2006).Available at: http://digitalcommons.law.scu.edu/lawreview/vol46/iss4/6 ${ }^{124}$ William J. Collins and Katharine L. Shester, The Economic Effects of Slum Clearance and Urban Renewal in the United States, Vanderbilt University Department of Economics, October 2010

${ }^{125}$ See for example Eminent Domain and Racial Discrimination: A Bogus Equation: Hearing Before the U.S. Comm'n on Civil Rights, Aug. 12, 2011 (Statement of J. Peter Byrne)
} 
American and Puerto Rican communities, ${ }^{126}$ thereby reinforcing racial segregation ${ }^{127}$ and leading critics to dub such programs "Negro Removal."

Martin Gold and Lynne Sagalin find that a "large and strong coalition of mutual interests supports redevelopment," including "city officials, redevelopment agencies, urban planners, real estate consultants and attorneys, developers, and environmental interest groups," making abuse of eminent domain more likely. Whereas the government may be held accountable by taxpayers for condemning property and then failing to use that property productively, private interests are less accountable. Thus, Nancy Kubasek and Garrett Coyle warn that

Because corporations do not face consequences if their estimates to the legislature differ from reality, a moral hazard problem is present: corporations have an incentive to overstate the number of jobs and the amount of tax revenue they will create given a suitable site. Moreover . . . the judiciary cannot review the likelihood that the public benefit targeted by the taking will be achieved. The logical corollary of this moral hazard problem is that legislatures may press for eminent domain condemnations to which they would never have consented had they known the actual or even likely outcomes. ${ }^{128}$

Likewise, llya Somin takes issue with the Court's deference to the legislature on this issue:

Among all the guarantees of the Bill of Rights, only the public use limitation is singled out for heavy [judicial] deference, ${ }^{, 129}$ [...] There is little sense in recognizing a constitutional right for the purpose of curbing abuses of government power, and then leaving the definition of that right up to the discretion of the very officials whose power the right is supposed to restrict. $^{130}$

The issues noted by Justices O'Connor and Kennedy have had negative impacts in practice. In the case of the Fort Trumbull neighborhood of New London, the subject of the Kelo ruling, the expropriation and demolition of the residential and commercial property in question was never followed by the promised economic development. Pfizer, the pharmaceutical company on behalf of which eminent domain was exercised, not only failed to develop the area but ended its operations

\footnotetext{
${ }^{126}$ Samuel Zipp Manhattan Projects: The Rise and Fall of Urban Renewal in Cold War New York 10

${ }^{127}$ Urban Renewal and Its Aftermath Jon C. Teaford Housing Policy Debate .

Volume 11, Issue 2

${ }^{128}$ Nancy Kubasek \& Garrett Coyle, A Step Backward Is Not Necessarily a Step in the Wrong Direction, 30 VT. L. REV. 43, 60-61 (2005) (citation omitted).

129 James W. Ely, Jr., "Poor Relation" Once More: The Supreme Court and the Vanishing Rights of Property Owners, 2005 CATO SUP.CT.REV. 39, 40-43

130 Ilya Somin, The Civil Rights Implications Of Eminent Domain Abuse, Testimony Before The United States Commission On Civil Rights, George Mason University, August 12 2011, accessed at http://www.law.gmu.edu/assets/files/faculty/Somin_USCCR-aug2011.pdf
} 
there. Instead of the expected hotel, conference center, condominium complex, health club, and shopping area, Fort Trumbull is now a "vast, empty field [...] entirely uninhabited."131 This was not an isolated incident: the "most famous economic development taking" prior to Kelo, Poletown Neighborhood Council v. City of Detroit, ${ }^{132}$ condemned a residential area in order to build a General Motors factory that likewise became an expensive failure. ${ }^{133}$

Following Kelo, economic growth has justified using eminent domain to acquire property even for development projects of questionable social utility, for example casinos in New Jersey. ${ }^{134}$ In New York City both the Columbia University Harlem expansion and the Atlantic Yards project were accused by opponents of "questionable determination of blight," collusion between developers and regulators, and ignoring community input. ${ }^{135}$ Furthermore, a 2012 study on "judicial biographies and takings decisions since 1975" concluded that "decisions favoring physical takings increase [economic] growth by $0.2 \%$ points but reduce minority home ownership and employment by $0.5 \%$ and $0.3 \%$ points respectively". ${ }^{136}$

Kelo drew adverse public and legislative reaction, including a 365-33 vote in the House of Representatives to condemn the ruling, denunciations from public figures and organizations across the political spectrum, and critical public opinion polls. ${ }^{137}$ Embracing Kelo's caveat that "nothing in our opinion precludes any State from placing further restrictions on its exercise of the takings power," and responding to the "intensity and broad-based, nonpartisan character of the backlash," 138 a large number of state legislatures passed some form of eminent domain reform. The Institute for Justice, which campaigned for eminent domain and blight standards reform following Kelo, asserts that 23 states have passed "substantive eminent domain reform" and 21 states have added lesser "eminent

\footnotetext{
${ }^{131} \mathrm{http} / / /$ www.bostonglobe.com/opinion/2014/03/12/the-devastation-caused-eminent-domainabuse/yWsyOMNEZ91TM94PYQIhOL/story.html; http://www.weeklystandard.com/articles/kelorevisited_776021.html?page=1

${ }^{132}$ Poletown Neighborhood Council v. City of Detroit, 304 N.W.2d 455, 457, 459 (Mich. 1981), overruled by County of Wayne v. Hathcock, 684 N.W.2d 765 (Mich. 2004).

${ }^{133}$ Ilya Somin, Overcoming Poletown: County of Wayne v. Hathcock, Economic Development Takings, and the Future of Public Use, 2004 MICH.ST.L.REV. 1005, 1016-19 (2004)

${ }^{134}$ Erin O'Neill, Atlantic City property owner fights eminent domain case, The Star-Ledger, May 202014

${ }^{135}$ Kate Klonick, Not in My Atlantic Yards: Examining Netroots' Role in Eminent Domain Reform, 100 Georgetown U. L. Rev. 263

${ }^{136}$ Daniel L. Chen and Susan Yeh, The Economic Impacts of Eminent Domain, January 2012; accessed at https://editorialexpress.com/cgi-bin/conference/download.cgi?db_name=NASM2012\&paper_id=530; For more on the harm to minorities and the poor, see Brief for the National Ass' $n$ for the Advancement of Colored People et al. as Amici Curiae Supporting Petitioners, Kelo, 545 U.S. 469 (2004) (No. 04 - 108), 2004 WL 2811057 ${ }^{137}$ See for example "Kelo v. City of New London: What it Means and the Need for Real Eminent Domain Reform," Institute for Justice, September 2005, accessed at http://www.castlecoalition.org/pdf/KeloWhite_Paper.pdf (criticism by a libertarian advocacy organization), "A win for big government," Washington Times, June 23, 2005; llya Somin, The Limits of Backlash: Assessing the Political Response to Kelo (June 11, 2009). Minnesota Law Review, Vol. 93, No. 6, pp. 2100-2178, June 2009; George Mason Law \& Economics Research Paper No. 07-14. Available at SSRN: http://ssrn.com/abstract=976298 (noting that critics included "Bill Clinton, then-Democratic National Committee Chair Howard Dean, and prominent African-American politician and California Representative Maxine Waters" as well as "The NAACP, the AARP, the liberal Southern Christian Leadership Conference.")

${ }^{138}$ Martin E. Gold and Lynne B. Sagalyn, The Use and Abuse of Blight in Eminent Domain, 38:4 Fordham Urb. L.J. 1119,1150 (2011)
}

Revista do Direito [ISSN 1982-9957]. Santa Cruz do Sul, v. 2, n. 49, p. 46-69, maio/ago. 2016. https://online.unisc.br/seer/index.php/direito/index 
domain protections" since 2005, leaving only six without significant reform. ${ }^{139}$ The intensity and effectiveness of these reforms varied: a few eliminated blight as a condition for eminent domain, others narrowed the definition of blight to more closely fit its original meaning as conditions "detrimental to or an actual danger to public health and safety," and still others narrowed the scope of blight determination to focus on individual units more than whole areas. ${ }^{140}$

Political science developed a considerable body of scholarship on what is called "capture theory." It refers to conditions in which private interests gain control of a public asset or process, and employ it to do their bidding, thus voiding its contribution to the common good. ${ }^{141}$ Capture comes in several forms including regulatory capture (when those that are to be regulated use the regulations to advance their special interests) and legislative capture (in which private interests pervert the democratic process, often by passing laws that seem to serve the public interest but actually rain down benefits on limited private groups). Capture is often achieved through campaign contributions, sometimes referred to as legalized bribery, and sometimes through illegal means. The preceding discussion of eminent domain suggests that the judicial process can also be captured. This is especially likely to occur when judges are elected rather than appointed and must raise camping funds in order to increase their chances of becoming elected, a recent trend.

All this shows that a sound liberal communitarian policy needs not merely a carefully crafted balance between the public interest and individual rights, and one that is recalibrated as conditions change significantly—but that it also requires ensuring that the purposes served are indeed public goods. This brings us full circle. We started by showing that one can distinguish the public good from those sought by private parties, and we now see that without such a clear line, there is a danger that the concept of public good will be abused by special interests, many of which serve neither the common good nor individual rights but merely their particular members.

\section{IN CONCLUSION}

We have seen the common good (or the public interest) can be defined and that liberal communitarian philosophy suggests that a good society will draw a carefully crafted balance between the common good and individual rights. Moreover, this balance will be recalibrated as historical conditions change. We found that the Court treatment of the First Amendment is much more willing to curb free speech for common goods that seem not to command nearly the same normative standing

\footnotetext{
${ }^{139}$ Legislative Center, Castle Coalition/Institute for Justice, 2014, accessed at http://www.castlecoalition.org/legislativecenter

${ }^{140}$ Martin E. Gold and Lynne B. Sagalyn, The Use and Abuse of Blight in Eminent Domain, 38:4 Fordham Urb. L.J. $1119,1157-9$ (2011). There is some debate over whether these measures have been effective, with Ilya Somin arguing that about half of state reforms have been ineffective, but Michael Allan Wolf disagreeing. See Ilya Somin, The Limits of Backlash: Assessing the Political Response to Kelo, 93:6 Minn. L. Rev 2100-2178 (2009); POWELL ON REAL PROPERTY § 79F.03[3][b][iv] (Michael Allan Wolf rev. online ed., LexisNexis 2009)

${ }^{141}$ See for example George Stigler, "The Theory of Economic Regulation," 2 Bell Journal of Economics 3 (1971); Richard A. Posner, "Theories of Economic Regulation," 5 Bell Journal of Economics 2 (1974); Sam Peltzman, "Toward a more general theory of regulation," 19 Journal of Law and Economics 2 (1976); Jean-Jacques Laffont and Jean Tirole, "The Politics of Government Decision-Making: A Theory of Regulatory Capture," 106 Quarterly Journal of Economics 4 (1991)
} 
as those the Court shortchanged. Free speech protection would be very little undermined if the Court set limits on hate speech similar to those society in effect has set, thus enforcing society's norms and incentives; if it protected more the sensibility of people burying their fallen heroes by keeping radical zealots further away and by shielding women seeking abortions from aggressive, in-your-face verbal abuse.

We saw that, in dealing with public safety as a common good, the Court came particularly close to the liberal communitarian positon, drawing on the text of the Fourth Amendment that bars only unreasonable searches and seizures. The Court made numerous specific rulings in this area, and provided different rationales for the various rulings, titling sometime to the public safety and sometimes to individual rights. One may argue whether, given the current conditions, it tiled too far toward promoting public safety or toward protecting individual rights. Likewise, one can agree that, in general, the Court followed a liberal communitarian approach in dealing with taking, in particular with eminent domain. The Court in effect created a whole area in which it allows individual rights, in particular private property, to be set aside in the service of one common good or another. However, in the process, it opened the door to fake public goods, which allow special interests to use the terminology and legal bases of eminent domain to serve not the public interests, but their private ones, Liberal communitarians need to draw on reforms instituted by many states to shore up the line that separate genuine from faux public goods.

\section{COMO CITAR ESSE DOCUMENTO:}

ETZIONI, Amitai. The standing of the public interest. Revista do Direito, Santa Cruz do Sul, v. 2, n. 49, maio 2016. ISSN 1982-9957. Disponível em: <https://online.unisc.br/seer/index.php/direito/article/view/7896>. Acesso em: doi:http://dx.doi.org/10.17058/rdunisc.v2i49.7896. 